\title{
The effect of dietary copper on the fatty acid composition and physical properties of pig adipose tissues
}

\author{
By J. H. MOORE ANd W. W. CHRISTIE \\ Hannah Dairy Research Institute, Ayr \\ AND R. BRAUDE AND K. G. MITCHELL \\ National Institute for Research in Dairying, Shinfield, Reading
}

(Received 24 fuly i968-Accepted 20 November 1968)

\begin{abstract}
I. Control groups of pigs were given a basal diet alone and treated groups received the same diet supplemented with $250 \mathrm{ppm}$ of copper. The animals were about 10 weeks of age at the start of the experiments and were killed when they weighed $90 \mathrm{~kg}$ live weight.

2. The ratio of oleic acid to stearic acid in the whole back fat (inner plus outer layers) was somewhat higher in the pigs given the copper supplement than in the control animals. The melting point of the back fat was about $10^{\circ}$ lower in the pigs given the copper supplement than in the control groups.

3. Separate analyses of the inner and outer layers of the back fat showed that the ratio of oleic acid to stearic acid in the outer fat layer of the control pigs, and in both the inner and the outer fat layers of the pigs given the copper supplement, was somewhat higher than that in the inner fat layer of the control animals. The melting point of the outer fat layer of the control pigs and of both back fat layers in the pigs given the copper supplement was IO-I $5^{\circ}$ lower than that of the inner fat layer of the control groups.

4. Evidence is presented that changes in the positional distribution of the fatty acids within the triglycerides of the back fats rather than differences in gross fatty acid composition are mainly responsible for the observed differences in physical properties.
\end{abstract}

It has been established that the addition of $250 \mathrm{ppm}$ of copper to the diet increases the growth rate of pigs and improves their feed conversion efficiency (Barber, Braude, Mitchell \& Cassidy, r955), but the site and mechanism of the action of the dietary copper is unknown. This topic has been reviewed by Braude (1965). The depot fats of copper-fed pigs have been reported to have slightly higher iodine values than the depot fats of control animals (Taylor \& Thomke, 1964) and this effect can be largely accounted for by alterations in the stearic acid:oleic acid ratios in the depot fats (Thomke \& Taylor, 1964). In some studies it was also observed that the depot fats of animals given copper-supplemented diets were apparently much softer (or had lower 'consistency' values) than those of control animals (Taylor \& Thomke, I964; Bowland \& Castell, I965). We have confirmed and extended these findings and now report a study of the effect of dietary copper on the fatty acid composition and melting point of the back fat of pigs.

\section{EXPERIMENTAL}

\section{Animals and diets}

The pigs were of the Large White breed. In all, five experiments were carried out and there were two feeding treatments in each experiment. After weaning at 8 weeks of age, the pigs were divided into two litter-mate groups of similar live 
weights. In all the experiments, there was a similar distribution of barrows and gilts between the two groups. In each experiment, one group of pigs was given a basal diet and the other was given the same diet supplemented with $25^{\circ} \mathrm{ppm}$ of copper (as $\mathrm{CuSO}_{4} \cdot 5 \mathrm{H}_{2} \mathrm{O}$ ). In Expt I, decorticated extracted groundnut meal was included in the basal diet, the composition of which was changed slightly when the pigs reached $55 \mathrm{~kg}$ live weight (Table I). In Expts 2-5, decorticated extracted groundnut meal was omitted from the basal diet, the composition of which was also changed slightly when the pigs reached $55 \mathrm{~kg}$ live weight (Table I). All pigs were individually fed twice daily, 31 . of water per $\mathrm{kg}$ of feed being added to the trough immediately before feeding. Two systems of feeding were employed in the investigation. In Expts $\mathrm{I}$ and 4 the amount of feed given was according to a scale based on live weight up to a daily maximum of 2.70 and $2.95 \mathrm{~kg} /$ pig respectively (Braude \& Mitchell, I95I). In Expts 2, 3 and 5, the pigs were given, at $18.5 \mathrm{~kg}$ live weight, I kg of feed which was subsequently increased by $0 \cdot 1 \mathrm{~kg} / \mathrm{pig}$ on each occasion that the troughs were found to be clean on 2 successive days, the pigs having access to the troughs for about $30 \mathrm{~min}$ at each feed; the maximum allowance of feed for each pig was $2 \cdot 95 \mathrm{~kg} /$ day.

The pigs were given the various diets from about to weeks of age until they reached $90 \mathrm{~kg}$ live weight, when they were slaughtered.

Table $\mathrm{I}$. Percentage composition of the basal diets given to the experimental pigs from 23 to $55 \mathrm{~kg}$ and from 55 to $90 \mathrm{~kg}$ live weight

\begin{tabular}{|c|c|c|c|c|}
\hline \multirow[b]{2}{*}{ Constituent } & \multicolumn{2}{|c|}{ Expt I } & \multicolumn{2}{|c|}{ Expts 2-5 } \\
\hline & $23-55 \mathrm{~kg}$ & $55-90 \mathrm{~kg}$ & $23-55 \mathrm{~kg}$ & $55-90 \mathrm{~kg}$ \\
\hline Barley meal & $5 I \cdot 75$ & 55.45 & 54.0 & $70 \cdot 0$ \\
\hline Weatings & $28 \cdot 0$ & $27 \cdot 5$ & $38 \cdot 0$ & $25 \cdot 0$ \\
\hline White fish meal & $2 \cdot 5$ & - & $7 \cdot 0$ & $3 \cdot 0$ \\
\hline Decorticated, extracted groundnut meal* & $15 \cdot 0$ & $15 \cdot 0$ & - & 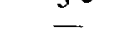 \\
\hline Limestone flour & 0.5 & $1 \cdot 25$ & $I \cdot 0$ & 0.75 \\
\hline Steamed bone flour & - & $\cdots$ & - & $1 \cdot 0$ \\
\hline Dicalcium phosphate & $\mathrm{I} \cdot 75$ & 0.5 & - & - \\
\hline Sodium chloride & 0.5 & 0.3 & - & 0.25 \\
\hline Vitamin A (i.u. $/ \mathrm{kg}) \dagger$ & 5000 & $275^{\circ}$ & 5000 & $275^{\circ}$ \\
\hline Vitamin $D_{3}$ (i.u. $\left./ \mathrm{kg}\right) \dagger$ & 1250 & 700 & $125^{\circ}$ & 700 \\
\hline
\end{tabular}

\section{Treatment of tissues}

Within approximately $20 \mathrm{~h}$ of slaughter, strips of back fat, about $2 \mathrm{~cm}$ in width, were taken from each pig. In Expts $1-3$, the adipose tissue lipids were extracted from the whole of the strips of back fat. In Expts 4 and 5, the strips were separated along the line of connective tissue between the inner and outer layers of back fat, and the adipose tissue lipids were extracted from each layer separately. The method of Folch, Lees \& Stanley (1957) was used for the extraction and purification of lipid samples. Thin-layer chromatography (TLC) of the lipid extracts indicated that triglycerides accounted for more than $95 \%$ of adipose tissue lipids. 


\section{Fatty acid analysis}

Fat samples were converted into the methyl esters of the constituent fatty acids with methanolic hydrogen chloride. Gas chromatographic analyses were carried out on columns of $5 \%(\mathrm{w} / \mathrm{w})$ polyethylene glycol adipate or $5 \%(\mathrm{w} / \mathrm{w})$ Apiezon $\mathrm{L}$ on Chromosorb W (I00-1 20 mesh, acid-washed and silanized; Phase Separations Ltd, Rock Ferry, Cheshire) in a Pye I04 Chromatograph (W. G. Pye Ltd, Cambridge).

\section{Melting points}

All traces of solvent were removed from the fat samples by placing them under high vacuum. A sample of fat was introduced into a glass capillary which was sealed and attached to a thermometer in a water bath equipped with a heater and stirrer. Softening of the fat could be observed over a range of several degrees but the point at which the sample became clear and entirely liquid was well defined and was taken as the melting point. The mean of several determinations on each sample was recorded.

\section{Randomization of fats}

Interesterification was carried out by a modification of the procedure of Luddy, Morris, Magidman \& Riemenschneider (I955). A sample of fat ( $0.25 \mathrm{~g}$ ) was maintained at $100^{\circ}$ in the presence of $2 \%(\mathrm{w} / \mathrm{w})$ sodium methoxide for $4 \mathrm{~h}$ under nitrogen. The mixture was then taken up in diethyl ether, washed first with dilute hydrochloric acid and then with water and dried over magnesium sulphate. Pure randomized triglycerides were obtained by preparative TLC with plates of silica gel G (E. Merk A.G. Darmstadt, Germany). The plates were $0.5 \mathrm{~mm}$ thick and the solvent system was hexane-diethyl ether, 95:5 (v/v). Partial hydrolysis of small samples of the product with pancreatic lipase as described by Luddy, Barford, Herb, Magidman \& Riemenschneider (1964) confirmed that the fatty acids were randomly distributed within the triglycerides.

\section{RESULTS AND DISCUSSION}

In three of the five experiments, the daily live-weight gain of the pigs given the copper-supplemented diets tended to be greater than that of the pigs given the control diets (Table 2). In four of the five experiments, the weight of feed consumed per $\mathrm{kg}$ of live-weight gain by the pigs given the copper-supplemented diets tended to be lower than the corresponding values for the pigs given the control diets (Table 2).

At least twenty-nine different fatty acids have been found in pig depot fats (Herb, Magidman, Barford \& Riemenschneider, r963; Magidman, Herb, Luddy \& Riemenschneider, 1963). In the samples of pig back fat examined in this study, however, only six were found to be present in appreciable concentrations-myristic, palmitic, stearic, palmitoleic, oleic and linoleic acids. Only trace concentrations of linolenic acid were detected. In Expts I--3, the fatty acid compositions of the whole back fat samples from control and copper-fed animals were determined (Table 3 ). The addition of copper to the diet of the pigs resulted in a somewhat lower concentration of stearic acid and a somewhat higher concentration of oleic acid in the back fat 
triglycerides; the concentrations of the other constituent fatty acids were unaltered by dietary copper. Similar results were described by Thomke \& Taylor (1964). Measurements of the 'consistency' of the fats by Taylor \& Thomke (I964) also indicated that the depot fat of copper-fed animals was much softer than that of the control animals. Although it seemed unlikely that such small differences in fatty acid composition could result in appreciable differences in the physical properties of the fats, determinations of the melting points of the samples of back fat in Expt 3 showed that they were $10^{\circ}$ higher in the control animals than in the pigs given the copper-supplemented diet.

Table 2. Expts 1-5. Daily gains in weight $(g)$ and feed conversion efficiencies of the pigs

(Mean values with their standard errors)

\begin{tabular}{|c|c|c|c|c|c|c|c|}
\hline \multirow[b]{2}{*}{$\begin{array}{l}\text { Expt } \\
\text { no. }\end{array}$} & \multirow{2}{*}{$\begin{array}{l}\text { No. } \\
\text { of pigs/ } \\
\text { treatment } \\
\text { group }\end{array}$} & \multicolumn{3}{|c|}{ Daily gain (g) } & \multicolumn{3}{|c|}{$\begin{array}{l}\text { Unit feed consumed per unit } \\
\text { live-weight gain }\end{array}$} \\
\hline & & $\begin{array}{l}\text { Control } \\
\text { diet }\end{array}$ & $\begin{array}{c}\text { Cul-supple- } \\
\text { mented } \\
\text { diet }\end{array}$ & $\begin{array}{l}\text { SE of } \\
\text { mean }\end{array}$ & $\begin{array}{c}\text { Control } \\
\text { diet }\end{array}$ & $\begin{array}{c}\text { Cu-supple- } \\
\text { mented } \\
\text { diet }\end{array}$ & $\begin{array}{l}\mathrm{SE} \text { of } \\
\text { mean }\end{array}$ \\
\hline I & 7 & 555 & 575 & I3.0 & $3 \cdot 59$ & 3.44 & 0.063 \\
\hline 2 & 7 & 628 & 706 & 25.7 & $3 \cdot 37$ & $3 \cdot 17$ & 0.068 \\
\hline 3 & 4 & 685 & 684 & $2 I \cdot 2$ & $3 \cdot 34$ & $3 \cdot 19$ & 0.071 \\
\hline 4 & 4 & 663 & 640 & 10.5 & 3.04 & $3 \cdot 15$ & 0.070 \\
\hline 5 & 8 & 735 & 801 & $18 \cdot 9$ & $3 \cdot$ I I & $2 \cdot 93$ & 0.044 \\
\hline
\end{tabular}

Table 3. Expts I, 2 and 3. Fatty acid composition (weight percentages of the total) and melting points $\left({ }^{\circ} \mathrm{C}\right)$ of whole back fat samples from control and copper-fed pigs

(Mean values with their standard errors)

\begin{tabular}{|c|c|c|c|c|c|c|c|c|c|}
\hline \multirow[b]{2}{*}{$\begin{array}{l}\text { Expt } \\
\text { no. }\end{array}$} & \multirow[b]{2}{*}{ Diet } & \multirow{2}{*}{$\begin{array}{l}\text { No. } \\
\text { of pigs/ } \\
\text { treatment } \\
\text { group }\end{array}$} & \multicolumn{6}{|c|}{ Fatty acid composition } & \multirow[b]{2}{*}{$\begin{array}{l}\text { Melting } \\
\text { point }\end{array}$} \\
\hline & & & Myristic & Palmitic & $\begin{array}{l}\text { Palmito- } \\
\text { leic }\end{array}$ & Stearic & Oleic & Linoleic & \\
\hline \multirow[t]{2}{*}{$\mathbf{I}$} & Control & 7 & $x \cdot 0$ & $26 \cdot 5$ & $\mathrm{I} \cdot 8$ & I $3 \cdot 8$ & $43 \cdot 7$ & 10.8 & - \\
\hline & $\begin{array}{l}\text { Cu-supplemented } \\
\text { SE of mean }\end{array}$ & $\frac{7}{-}$ & $\begin{array}{l}1.0 \\
0.06\end{array}$ & $\begin{array}{l}26.0 \\
0.95\end{array}$ & $\begin{array}{l}I \cdot 9 \\
0 \cdot I I\end{array}$ & $\begin{array}{c}\text { II } 3 \\
0 \cdot 38\end{array}$ & $\begin{array}{l}45^{\cdot 9} \\
0.56\end{array}$ & $\begin{array}{l}\text { II'I } \\
0.59\end{array}$ & - \\
\hline \multirow[t]{2}{*}{2} & Control & 7 & $I \cdot I$ & $27 \cdot 7$ & $2 \cdot 2$ & 13.7 & $42 \cdot 8$ & $9^{.9}$ & - \\
\hline & $\begin{array}{l}\text { Cu-supplemented } \\
\text { SE of mean }\end{array}$ & 7 & $\begin{array}{l}I \cdot I \\
0 \cdot 06\end{array}$ & $\begin{array}{l}27 \cdot 9 \\
I \cdot I I\end{array}$ & $\begin{array}{l}3 \cdot 0 \\
0 \cdot 23\end{array}$ & $\begin{array}{l}10.0 \\
0.50\end{array}$ & $\begin{array}{l}45 \cdot 9 \\
0.75\end{array}$ & $\begin{array}{l}9.7 \\
0.50\end{array}$ & - \\
\hline \multirow[t]{2}{*}{3} & Control & 4 & I.O & $27 \cdot 6$ & $2 \cdot 1$ & I $2 \cdot 8$ & $44 \cdot 9$ & I $1 \cdot 6$ & 39 \\
\hline & Cu-supplemented & 4 & $I \cdot I$ & $27 \cdot 1$ & $2 \cdot 6$ & 10.8 & $46 \cdot 1$ & $12 \cdot 3$ & 29 \\
\hline
\end{tabular}

Pig back fat is deposited in two distinct layers separated by connective tissue and, in an earlier study, many years before copper was routinely incorporated in pig diets, Dean \& Hilditch (I933) observed that the oleic acid: stearic acid ratio in the inner layer was lower than that in the outer layer and that the outer fat was softer than the inner fat. Accordingly, in Expts 4 and 5, the inner and outer portions of the back fats were separated and the fatty acid composition of each was determined independently (Table 4).

The fatty acid composition of the inner back fat of the control pigs was markedly 
different from the composition both of the outer back fat of the control pigs and of the inner and outer back fats of the copper-fed pigs. The main differences observed were in the concentrations of stearic and oleic acids. In the inner back fat of the control pigs, the concentration of stearic acid was $3-5 \%$ higher and the concentration of oleic acid was $3-5 \%$ lower than in the outer back fat of the control pigs and in the inner and outer back fat of the copper-fed pigs. The melting point of the inner

Table 4. Expts 4 and 5. Fatty acid compositions (weight percentages of the total) and melting points $\left({ }^{\circ} \mathrm{C}\right)$ of inner and outer layers of back fat from control and copper-fed pigs

(Mean values with their standard errors)

\begin{tabular}{|c|c|c|c|c|c|c|c|c|c|c|}
\hline \multirow[b]{2}{*}{$\begin{array}{c}\text { Expt } \\
\text { no. }\end{array}$} & \multirow[b]{2}{*}{ Diet } & \multirow{2}{*}{$\begin{array}{l}\text { No. } \\
\text { of pigs } \\
\text { treatment } \\
\text { group }\end{array}$} & \multirow[b]{2}{*}{$\begin{array}{l}\text { Type of } \\
\text { back fat }\end{array}$} & \multicolumn{6}{|c|}{ Fatty acid composition } & \multirow[b]{2}{*}{$\begin{array}{l}\text { Melting } \\
\text { point }\end{array}$} \\
\hline & & & & Myristic & Palmitic & $\begin{array}{l}\text { Palmito- } \\
\text { leic }\end{array}$ & Stearic & Oleic & Linoleic & \\
\hline 4 & $\begin{array}{l}\text { Control } \\
\text { Cu-supplemented } \\
\text { SE of mean }\end{array}$ & $\begin{array}{l}4 \\
4 \\
-\end{array}$ & $\begin{array}{c}\text { Inner } \\
\text { Inner } \\
-\end{array}$ & $\begin{array}{l}I \cdot 4 \\
I .6 \\
0.21\end{array}$ & $\begin{array}{l}28 \cdot 1 \\
28 \cdot 0 \\
1 \cdot 02\end{array}$ & $\begin{array}{l}2 \cdot 3 \\
2 \cdot 8 \\
0 \cdot 33\end{array}$ & $\begin{array}{l}\text { I } 7 \cdot 6 \\
15 \cdot 5 \\
1 \cdot 32\end{array}$ & $\begin{array}{l}40 \cdot 8 \\
42 \cdot 5 \\
I \cdot 39\end{array}$ & $\begin{array}{l}9 \cdot 8 \\
9 \cdot 6 \\
0 \cdot 46\end{array}$ & $\begin{array}{l}45 \\
33 \\
0.8 \mathrm{I}\end{array}$ \\
\hline 5 & $\begin{array}{l}\text { Control } \\
\text { Cu-supplemented } \\
\text { SE of mean }\end{array}$ & $\begin{array}{l}8 \\
8 \\
-\end{array}$ & $\begin{array}{l}\text { Inner } \\
\text { Inner } \\
-\end{array}$ & $\begin{array}{l}\text { I.7 } \\
\text { I. } 8 \\
0.09\end{array}$ & $\begin{array}{c}28 \cdot 3 \\
28 \cdot 0 \\
0 \cdot 51\end{array}$ & $\begin{array}{l}2 \cdot 6 \\
3 \cdot 7 \\
0 \cdot 25\end{array}$ & $\begin{array}{l}17 \cdot 8 \\
14.0 \\
0.70\end{array}$ & $\begin{array}{c}40 \cdot 7 \\
44 \cdot 8 \\
0.87\end{array}$ & $\begin{array}{l}8 \cdot 9 \\
7 \cdot 6 \\
0 \cdot 31\end{array}$ & $\begin{array}{l}43 \\
34 \\
0.90\end{array}$ \\
\hline 4 & $\begin{array}{l}\text { Control } \\
\text { Cu-supplemented } \\
\text { SE of mean }\end{array}$ & $\begin{array}{r}4 \\
4 \\
\end{array}$ & $\begin{array}{c}\text { Outer } \\
\text { Outer } \\
-\end{array}$ & $\begin{array}{l}1 \cdot 6 \\
1 \cdot 6 \\
0 \cdot 26\end{array}$ & $\begin{array}{l}26 \cdot 4 \\
26 \cdot 4 \\
I \cdot 02\end{array}$ & $\begin{array}{l}2 \cdot 7 \\
3 \cdot 5 \\
0 \cdot 53\end{array}$ & $\begin{array}{l}\mathrm{I} 4 \cdot 5 \\
\mathrm{I} 3 \cdot 2 \\
\mathrm{I} \cdot 02\end{array}$ & $\begin{array}{r}43 \cdot 8 \\
44 \cdot 6 \\
I \cdot 5 I\end{array}$ & $\begin{array}{c}11 \cdot 0 \\
10.7 \\
0.73\end{array}$ & $\begin{array}{l}33 \\
36 \\
0.92\end{array}$ \\
\hline 5 & $\begin{array}{l}\text { Control } \\
\text { Cu-supplemented } \\
\text { SE of mean }\end{array}$ & $\begin{array}{l}8 \\
8 \\
-\end{array}$ & $\begin{array}{l}\text { Outer } \\
\text { Outer }\end{array}$ & $\begin{array}{l}\text { I.7 } \\
\text { I.9 } \\
0.11\end{array}$ & $\begin{array}{c}27.3 \\
26 \cdot 9 \\
0.68\end{array}$ & $\begin{array}{l}2 \cdot 9 \\
4 \cdot 3 \\
0 \cdot 21\end{array}$ & $\begin{array}{c}\text { I } 4.9 \\
\text { I I. } 8 \\
0.62\end{array}$ & $\begin{array}{c}43.6 \\
46.7 \\
0.62\end{array}$ & $\begin{array}{l}9.8 \\
8.4 \\
0.38\end{array}$ & $\begin{array}{l}30 \\
32 \\
I \cdot 6\end{array}$ \\
\hline
\end{tabular}

Table 5. Comparison of the fatty acid compositions (weight percentages of the total) and melting points $\left({ }^{\circ} \mathrm{C}\right)$ of back fats obtained from some individual pigs

\begin{tabular}{|c|c|c|c|c|c|c|c|c|c|}
\hline \multirow[b]{2}{*}{ Pig no. } & \multirow[b]{2}{*}{ Diet } & \multicolumn{7}{|c|}{ Fatty acid composition } & \multirow[b]{2}{*}{$\begin{array}{c}\text { Melting } \\
\text { point }\end{array}$} \\
\hline & & $\begin{array}{l}\text { Type of } \\
\text { back fat }\end{array}$ & Myristic & Palmitic & $\begin{array}{l}\text { Palmito- } \\
\text { leic }\end{array}$ & Stearic & Oleic & Linoleic & \\
\hline I & Control & Inner & $1 \cdot 6$ & $28 \cdot 7$ & $3 \cdot I$ & I $5 \cdot I$ & $42 \cdot 5$ & $8 \cdot 2$ & 4I \\
\hline 2 & Control & Outer & $\mathbf{I} \cdot 8$ & $26 \cdot 5$ & $2 \cdot 7$ & I 5.8 & $42 \cdot 7$ & 10.5 & 32 \\
\hline 3 & Cu-supplemented & Inner & $2 \cdot 0$ & $28 \cdot 9$ & 3.3 & 14.9 & $43 \cdot 6$ & $7 \cdot 3$ & 34 \\
\hline 4 & Cu-supplemented & Outer & I $\cdot 8$ & $29 \cdot 5$ & $2 \cdot 6$ & I5.8 & $42 \cdot 1$ & $8 \cdot 2$ & 29 \\
\hline
\end{tabular}

back fat of the control pigs was $10-15^{\circ}$ higher than that of the fat from the outer layer of the control pigs and from the inner and outer layers of the copper-fed pigs. Therefore, it appeared that the effects of dietary copper on the fatty acid composition and physical properties of pig back fat were located principally in the inner layer. However, it seemed unlikely that such large differences in melting point could be explained solely on the basis of the small observed differences in fatty acid composition. For instance, it is possible to select fats from individual animals that have similar fatty acid compositions but quite different melting points (Table 5).

Pig depot fats consist almost entirely of triglycerides and it is well known that differences in the distribution of the fatty acids can markedly affect the physical 
properties of the glycerides. Thus, triglycerides can have the same fatty acid composition, but quite different melting points if the distributions of fatty acids within the glycerides are different. To check whether the marked differences in melting points were due to differences in the positional distribution of the fatty acids in the back fat triglycerides, samples of the inner and outer back fats from the control and copper-fed animals were interesterified to distribute the fatty acids randomly between the I-, 2- and 3-positions of the glyceride molecules. Random interesterification resulted in a decrease in the melting point of the inner back fat triglycerides from the control animals, whereas it resulted in an increase in the melting points of the back fat from the outer layer of the control animals and from the inner and outer layers of the copper-fed animals (Table 6). It seems likely, therefore, that there were differences in glyceride structure between the inner back fat of the control pigs and the back fats obtained from the outer layer of the control pigs and from the inner and outer layer of the copper-fed pigs. There is known to be a rather unusual distribution of fatty acids between the I-, 2- and 3-positions in pig triglycerides (Brockerhoff, Hoyle \& Wolmark, 1966). Detailed analyses of the glyceride structure of the back fats from the control and copper-fed animals are in progress and will be reported later.

Table 6. Melting points $\left({ }^{\circ} \mathrm{C}\right)$ of some representative samples of back fat from individual pigs, before and after random interesterification

\begin{tabular}{clccc} 
Pig no. & \multicolumn{1}{c}{ Diet } & $\begin{array}{c}\text { Type of } \\
\text { back fat }\end{array}$ & $\overbrace{\text { Before }}^{\text {Melting point }}$ & After \\
5 & Control & Inner & 45 & 39 \\
6 & Control & Inner & 44 & 37 \\
6 & Control & Outer & $\mathbf{2 8}$ & 36 \\
7 & Cu-supplemented & Inner & $3 \mathbf{3}$ & 38 \\
8 & Cu-supplemented & Inner & 34 & 39 \\
8 & Cu-supplemented & Outer & 32 & 37
\end{tabular}

The reason for the effect of copper on lipid metabolism in the pig is unknown. It is possible that it is in part in some way related to, or influenced by, the wellestablished overall growth-promoting effect of high copper supplements in the diet of growing pigs. However, the results for the relatively small number of pigs in the five experiments reported in this paper are inadequate to permit any satisfactory conclusions to be drawn, and further work on this aspect of the problem is now in progress. Taylor \& Thomke (1964) have speculated that dietary copper might affect fat absorption or transport, or that the high level of copper found in the liver of animals on copper-supplemented diets might affect the normal fat metabolism of this tissue. Detailed analyses of the lipids of many more tissues will be necessary, however, before the true mode of action of dietary copper on lipid metabolism in the pig, and the site of the reaction, can be positively determined.

The authors gratefully acknowledge the skilled technical assistance of Miss A. Broadbent and Miss E. K. Skinner. 


\section{REFERENCES}

Barber, R. S., Braude, R., Mitchell, K. G. \& Cassidy, J. (1955). Chemy Ind. 74, 60I.

Bowland, J. P. \& Castell, A. G. (1965). 44th Annual Feeders' Day, University of Alberta 50, I8.

Braude, R. (1965). Transactions of the Symposium on Cuprum Pro Vita, Vienna, p. 55.

Braude, R. \& Mitchell, K. G. (I951). F. Minist. Agric. Fish. 57, 501.

Brockerhoff, H., Hoyle, R. J. \& Wolmark, N. (1966). Biochim. biophys. Acta 116, 67.

Dean, H. K. \& Hilditch, T. P. (1933). Biochem. F. 27, I950.

Folch, J., Lees, M. \& Stanley, G. H. S. (1957). F. biol. Chem. 226, 497.

Herb, S. F., Magidman, P., Barford, R. A. \& Riemenschneider, R. W. (1963). F. Am. Oil Chem. Soc. 4o, 83 .

Luddy, F. E., Barford, R. A., Herb, S. F., Magidman, P. \& Riemenschneider, R. W. (1964). F. Am. Oil Chem. Soc. 4r, 693 .

Luddy, F. E., Morris, S. G., Magidman, P. \& Riemenschneider, R. W. (1955). F. Am. Oil Chem. Soc. $32,522$.

Magidman, P., Herb, S. F., Luddy, F. E. \& Riemenschneider, R. W. (1963). 7. Am. Oil Chem. Soc. 40, 86.

Taylor, M. \& 'Thomke, S. (1964). Nature, Lond. 2oI, 1 246.

Thomke, S. \& Taylor, M. (1964). Paper presented at the Ioth Conference of European Meat Research Workers, Roskilde. 